\title{
Pre-Service Teachers' Belief on Professional Development: A study on ESP Teacher
}

\author{
Aisyah, Bayu Hendro Wicaksono \\ Postgraduate School, University of Muhammadiyah Malang-Indonesia. \\ bayuhw@yahoo.com
}

\begin{abstract}
Guskey (2002) asserted that professional development is seen as a beneficial practice to disclosed the change required in teachers profession. Indeed, teacher's belief is becoming one of the driving forces which led to the practice in regards. In fact, Some of the ESP instructors seem to find it difficult to deal with the practice of professional development. This is the situation happened in Language Center, the center of ESP program, at my institution. Although some research have been investigating the case of teacher belief within professional development, but little research conducted in ESP course at Indonesian Universities context. Thus, this present study is designed at finding 1) the pre-service teachers' beliefs in being professional language teachers in teaching ESP, and 2) the professional activities undertaken by the pre-service teachers to develop their professionalism in teaching ESP. Through the explanatory research, a chosen ESP pre-service teachers participated in this study. The data from it were generated from survey, observation and interview to have a saturated information. These methods were on purpose to validate the data. The finding showed that being professional language teachers has fallen on eight indicators which are different from some other related research. The finding also gave information on four types of famous activities undertaken by the pre-service teacher.
\end{abstract}

Keywords: Teachers' belief, Pre-service Teachers, Professional Development, The Teaching of ESP

\section{INTRODUCTION}

The issue of teacher professional development obtains a serious attention by Indonesian government. It is supported by the establishment of Permendikbud No. 87 Tahun 2013 about the training for teacher as a profession $(P P G)$. It is a form of confession and support for teachers to develop their professionalism. The professional development activities should enhance the teachers' basic competencies; pedagogic competence, social competence, personal competence and professional competence (UU No. 14 Tahun 2005 \& Permendiknas No. 16 Tahun 2007). The professional teachers are expected to be able to achieve the goal of education as mandated in the opening of the 1945 constitution. In sum, the establishment of these laws convince the teachers that professional development has a crucial role in the development of education. Donaghue (2003) claims that teachers' beliefs play an essential role in the teacher development process, especially in the concurrence of new approaches, techniques, and activities. In other words, teachers' personal beliefs about language teaching, learners and teacher's roles guide teachers in their actual classroom practices. In addition, Johnson (1992) claims that teachers enter the field of education with preconceived beliefs about teaching and learning that guide their classroom practices. These beliefs are influenced by some factors such as teachers' teaching experience and competence (Fives \& Buehls, 2012). The longer teaching experience and higher proficiency level that teachers have, the better teaching practices they will show. The improving of teaching practice that the teachers show will reflect the teachers' professionalism. Departing from elaborated crucial issues and previous studies, the researcher wants to conduct a research to 
investigate ESP pre-service teachers' beliefs on being professional language teachers at University of Muhammadiyah Malang (UMM), as it offers the teaching of ESP for all the non-English language education programs as one of the compulsary subjects, and the way the teachers develop their professionalism.

Professional development has become a crucial goal of teachers' educational system in many countries. Guskey (2002) stated that professional development is a systematic program that aimed to convey change in the classroom practice of teachers in line with their beliefs, attitudes and in learners' learning result. It has been seen as the way for teachers as professional to not only broaden their knowledge of a particular discipline but also to fulfill their teaching qualification and professional norms ( $\mathrm{Lv}, 2014)$. In other words, professional development is the key to keeping teachers abreast of current issues in education, helping them implement innovations, refine their practice, and broaden themselves, both as educators and as individuals (Craft, 2000). In sum, involving in professional development activities is indeed important to broaden teachers' knowledge and skills in order to achieve the educational goals.

In the practice of professional development, Mora, Trejo, \& Roux (2014) proposed three different approaches; the individual professional development approach, institutional professional development, and teacher-led professional development. The individual professional development sees teacher as the one who is responsible to drive his or her inner motivation to involve in a particular professional development activities (Craft, 2000). The institutional professional development sees the policy makers or people with high authority in educational setting as people who are responsible to provide their teachers with opportunity to involve in certain professional development activities (Craft, 2000; Day, 1999). While the teacher-lead professional development puts teachers as the center of all educational undertaking. The teachers may participate in their own professional development, but they have to consider the balance of institutional and individual needs. Thus, the approaches to professional development show that all people in educational setting have their own responsibility to help teachers gain success in the professional development activities.First, confirm that you have the correct template for your paper size. This template has been tailored for output on the A4 paper size. If you are using US letter-sized paper, please close this file and download the file "MSW_USltr_format".

There have been many studies that focus to discuss the idea of belief from different perspectives. Belief is seen as one of the crucial factors that influences a person or a group of people's actions or behaviors. Pajares (1992:316) explains belief as an individual's reasoning of the truth or falsity of a proposition, a reasoning that can only be inferred from a collective conception of what people say, intend, and do. From the definition, it can be seen that one of the characteristics of belief is subjectivity. Subjectivity means that different individual is possibly to have the same or different judgment about particular occurrences. Pajares (1992) also emphasizes the function of collective understanding as the source of someone's belief. Collective understanding means the understanding toward particular thing that is shared by mostly people. For instance, if mostly people tend to behave in certain manner toward particular condition, it means that the manner is acceptable in the society.

\author{
CELTIC: A Journal of Culture, English Language Teaching, Literature \& Linguistics \\ PISSN 2356-0401 EISSN 2621-9158 \\ VOLUME 5 NO 22018
}


The term beliefs are very closely related to preferences. Some studies define beliefs as personal judgments about particular condition that is accepted as true by the individuals and does not need to be substantied by any evidence (Hawanti, 2012; Pajares, 1992). It means that belief is a subjective thing that hard to be changed and strongly involves feelings and emotions. In educational context, teachers' beliefs are possible to change but it needs a very long-time process and involves various experiences (Grijalva \& Brajas, 2013; Ozmen, 2012). Moreover, preferences are individuals' degree of choice on something (Bada \& Okan, 2000). Preference is also a subjective thing but it is changeable anytime because of particular conditions and does not need to pass long-time process and experience. For instance, some learners admit that they prefer to be more active in particular lesson just because of the teachers' appearance and personality. If a teacher is good-looking and have a sense of humor, they prefer to show high enthusiastic during the classroom instruction. However, if the same teacher is suddenly being monotonous, the learners will also show low enthusiastic during the activities.

In educational context, beliefs become one of the pivotal factors that influence the successful of teachers' teaching practice (Borg, 2001; Kalaja, Barcelos, Aro, \& Lyhty, 2015; Liando, 2010). Beliefs act as referents for actions, and can be interpreted as what and why a teacher accomplished a goal (Ismail, 2007:67). Johnson (1999:30) points out that beliefs have a cognitive, an affective, and a behavioral element that have influence on what people know, feel, and do. Teachers are professionals who make reasonable judgments and decisions within a complex and uncertain community, school and classroom environments. The judgments and decision made by teachers are driven by their belief system. In addition, teachers' thinking about their roles and the beliefs they hold, help them shape their pedagogy.

Some studies found that there are some factors that affect teachers' personal beliefs. Borg (2003) explains that the personality, educational, and professional experiences in the teachers' life commonly have a powerful influence on the improvement of their teaching practices. Graves (2000) suggested that teachers' beliefs are based on their learning experiences, working experiences and places, and their ongoing professional development. Moreover, Richardson (1996) pointed out three types of experiences, which include personal experience, experience with schooling and instruction, and experience with formal knowledge. They have primarily influenced the development of beliefs about and knowledge of teaching.

The concept of pre-service teacher in this context of study is derived from the teachers' obligations as mandated in Indonesian educational regulation. According to Undang-undang No.14 Tahun 2005-chapter VI-part 1 article 8, those who are considered as teachers are obliged to possess academic qualification, executed the teacher's competence, educator certificate, physically and mentally health, and possess the ability to actualize the educational goal.

From the law, the teachers' academic qualification can be obtained by finishing their tertiary level of education from particular university with at least bachelor or diploma four degree in particular subjects (article 9). Those teachers also have to possess the teachers' basic competences such as pedagogical competence, personal competence, social competence, and professional competence that can be learned deeper by attending professional training (article 10). However, the educator certificate will be

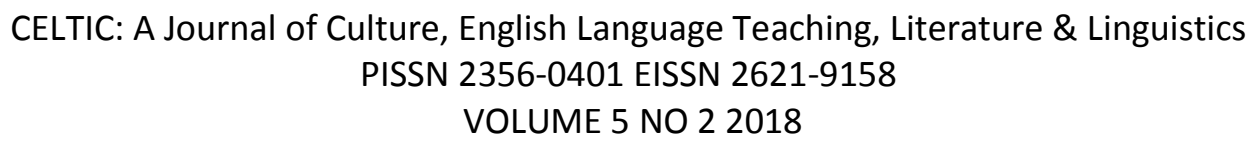


obtained if the teachers are able to fulfill the requirement and pass from particular teacher professional training as mandated in the law (article 11).

Based on Undang-undang No.14 Tahun 2005 tentang Guru dan Dosen, the educator certificate is obtained by attending certification program that is held by particular universities that have fulfilled the national standard of certification program caretaker. Moreover, since the establishment of Permendikbud No.87 Tahun 2013, the educator certificate can also be obtained through pre-service teacher training for profession $(P P G)$ program. These two types of educational programs are held as a support for Indonesian teachers to improve their professionalism as teachers whose main work is to educate people. In sum, having the certificate educator is indeed beneficial for the teachers to obtain confession as professional.

From the explanation above, the researcher concludes that when all the crucial obligations that should be obtained by a teacher are not completed yet, then the teacher is considered as a pre-service teacher, not absolutely a full teacher. This concept of preservice teachers is appropriate to draw the condition of those who teach ESP course at UMM. They have graduated from English language education department but they still hold bachelor degree (S1). Because they are working at a university, it should refer back to Undang-undang No. 14 Tahun 2005 in which those who are considered as a lecturer has to fulfill at least the academic qualification with master degree (S2). Nevertheless, the researcher finds that there are some of the ESP pre-service teachers that are studying as postgraduate learners. Therefore, by referring to the explanation above, the researcher concludes that the ESP pre-service teachers in her study are those who are still active in teaching ESP course at UMM and they are studying at particular postgraduate program in Malang.The template is used to format your paper and style the text. All margins, column widths, line spaces, and text fonts are prescribed; please do not alter them. You may note peculiarities. For example, the head margin in this template measures proportionately more than is customary. This measurement and others are deliberate, using specifications that anticipate your paper as one part of the entire proceedings, and not as an independent document. Please do not revise any of the current designations.

\section{Method}

This present study aimed to investigate the ESP pre-service teachers' beliefs about being professional teachers and the way pre-service teachers develop their professionalism. Regarding to the aims of this study, the researcher chose mixedmethod design which was considered appropriate to be employed. Creswell (2012:535) reveals that mixed-method design is a procedure which involves both quantitative and qualitative methods in order to gain comprehensive evidences and in-depth understanding to the research questions. In sum, employing mixed-method design that allowed researcher to use various methods which were beneficial to understand the data of the research.

In this present study, the researcher applied an explanatory sequential design. Creswell (2012:542) conceives explanatory sequential design as a design of study that is done in two phases, first collecting the quantitative data to provide the general picture of the research questions then followed by collecting the qualitative data to refine, extend or explain the quantitative data. In this study, the researcher focused on the investigation 
of the ESP pre-service teachers' beliefs in being professional teachers that dealt with quantitative data and the process to develop their professionalism dealt with qualitative data. Thus, due to the nature of each research question, applying an explanatory sequential design was appropriate to help the researcher in completing the research.

\section{Setting and Participants of the Study}

The researcher chose UMM as the setting of this present study based on some reasons. Firstly, several studies found that the main problem in teaching ESP is the teachers' professionalism. The ESP teachers' professionalism was still low in terms of several points such as providing the improper ESP teaching materials and lack of terminology knowledge based on learners' specialization (Al-Zahrani, 2014; Cao, 2014; Ghanbari \& Rasekh, 2012). Based on the result of observation and interview, the same problems occurred in ESP teaching of UMM. The pre-service teachers showed that they still have difficulties in providing the appropriate teaching materials since they were also lack of specific terminology in learners' specialization. Secondly, LC of UMM provides special awards as a form of confession for the ESP teachers' effort to develop professionalism. Therefore, UMM was appropriate to be chosen as the setting of this present study.

The participants of this research were chosen by using purposive sampling. In purposive sampling, the researcher intentionally selects individuals and sites by proposing some standards in order to obtain rich and useful data (Creswell, 2012:206). In this present study, the researcher limited the participants by proposing some criteria. Firstly, the participants should graduate from English education program. Secondly, the participants are still studying at particular university as postgraduate learners. Thirdly, the participants have experience in joining particular professional development activities. The last, the participants experience in teaching ESP at UMM minimally two years.

Based on the criteria above, the researcher found there were 15 pre-service teachers as the participants. Those 15 pre-service teachers were used as the main source of data for the first research question while for the second research question the researcher only used six out of 15 pre-service teachers. The researcher used six pre-service teachers as the source of the data dealing with the second research question because the pre-service teachers had some teaching schedules that were not happened at the same time. So, the researcher could observe and interview those pre-service teachers objectively at different time.

\section{Data Collection}

Data collection is the process of gathering and measuring information on variables of interest by planning five basic steps: selecting the participants, gaining permission, selecting the data needed, designing the instruments and administering the data collection (Creswell, 2012; Fraenkel \& Wallen, 2009). These steps were pivotal to conduct because it determined the accurate answers of all research questions.

\section{Finding and Discussion}

The results of data analysis showed that there were eight pivotal indicators of being professional language teachers. They were: 1) understanding the roles of teachers, 2) 
having inclusive attitude and indiscriminative behavior, 3) developing language teaching and learning material creatively, 4) developing the profession continually through reflective action, 5) having passion in teaching, 6) conducting educative teaching, 7) conducting assessment and evaluation of the learning process, and 8) utilizing technology, information, and communication for self-development. The average percentage of each indicator showed which indicators became the most important for the pre-service teachers. The detail description is presented in table 4.1.

Table 4.1 The Average Score of Pre-service Teachers' Beliefs

\begin{tabular}{lllllll}
\hline No. Indicators & TI & TIS & TRA & RAA & $\begin{array}{c}\text { AP } \\
(\%)\end{array}$ \\
\hline 1 & $\begin{array}{l}\text { Understanding the roles of } \\
\text { teachers. }\end{array}$ & 4 & 16 & 212 & 14.13 & 88.31 \\
& 4 & 16 & 207 & 13.80 & 86.25 \\
3 & $\begin{array}{l}\text { Having inclusive attitude and } \\
\text { indiscriminative behavior. }\end{array}$ & 5 & 20 & 256 & 17.06 & 85.30 \\
$\begin{array}{l}\text { Developing language teaching and } \\
\text { learning material creatively. }\end{array}$ & 4 & 16 & 204 & 13.60 & 85.00 \\
$\begin{array}{l}\text { Developing the profession } \\
\text { continually through reflective }\end{array}$ & 3 & 12 & 152 & 10.13 & 84.41 \\
6 & $\begin{array}{l}\text { action. } \\
7\end{array}$ & 7 & 28 & 329 & 21.93 & 78.32 \\
$\begin{array}{l}\text { Having passion in teaching. } \\
\text { Conducting educative teaching. }\end{array}$ & 4 & 16 & 177 & 11.80 & 73.75 \\
8 & $\begin{array}{l}\text { Conducting assessment and } \\
\text { evaluation of the learning process. }\end{array}$ & 4 & 16 & 173 & 11.53 & 72.06 \\
$\begin{array}{l}\text { Utilizing technology, information, } \\
\text { and communication for self- } \\
\text { development. }\end{array}$ & & & & & \\
\hline
\end{tabular}

Notes

TI : Total Items

TIS : Total Items Score

TRA : Total Respondents' Answer

RAA : Respondents' Answers Average

AP : Average in Percentages

Table 4.1 showed that the average percentage of the items was $81.67 \%$. It means that the pre-service teachers highly believed that professional language teachers needed to prepare themselves by learning continually in order to understand at least the eight important indicators above. Besides, the table also reported that understanding the roles of teachers became the most important indicator of professional language teacher with the average percentage of $88.31 \%$. Professional teachers had to understand every teachers' role and to apply the appropriate roles based on the classroom condition. Being aware of showing a good language model and becoming a friend for learners 
were the examples of the teachers' roles that needed to be understood by a professional language teacher.

Having inclusive attitude and indiscriminative behavior with the average percentage of $86.25 \%$ became the second important indicator of a professional language teacher. Accordingly, professional language teachers should treat their learners fairly and equally during the activities and open to criticism from anyone including the learners. In addition, developing language teaching and learning material creatively with the average percentage of $85.30 \%$ was the third indicator of being professional language teachers. The implication of this indicator made professional language teachers should be able to provide the appropriate and interesting media in teaching. A professional language teacher also had to promote the use of authentic materials in language teaching in order to provide learners with various types of language use.

The fourth indicator of being a professional language teacher was to be able to develop the profession continually through reflective actions with the average of percentage of $85 \%$. Consequently, professional teachers should always evaluate their own teaching. It was essential to help them improve their weaknesses which could be done through self-reflection. In addition, having a passion for teaching was the fifth indicator of being a professional language teacher with the average percentage of $84.41 \%$. The indications of that is enjoying checking learners' assignment and being disciplined with all duties in teaching.

Conducting educative teaching with the average percentage of $78.32 \%$ was the sixth indicator of professional language teachers. It could be done by having the knowledge about the variety of language teaching techniques or strategies. In addition, being able to conduct assessment and evaluation of the learning process obtained the average percentage of $73.75 \%$. It was more effective for teachers to evaluate their learners during the classroom process. Providing activities that promoted learners to use English in a specific context was also beneficial as professional teachers.

Finally, $72.06 \%$ of the pre-service teachers claimed that it is essential for professional language teachers to utilize technology, information and communication for self-development. Professional language teachers had to use their free time to read any information from the internet in order to improve their competence. Sometimes, professional teachers might utilize e-mail as media for learners to submit their assignment because of the flexibility.

The pre-service teachers revealed that doing peer observation helped them in finding their strengths and weaknesses in teaching. The observer objectively provided them with the notes about the activities occurred during their teaching performance. Sometimes, the pre-service teachers shocked with the result of doing peer observation. For instance, the pre-service teachers unconsciously only talked to particular learners during the activity. This condition made the other learners envious because they did not obtain the same attention from the teachers. By knowing the fact from the observer's notes, the pre-service teachers considered the step of changes that they needed to do in order to enhance their teaching quality.

In addition, the pre-service teachers explained that they also did other selfinitiated activities to improve their knowledge. The activity was to do on-line updating. The pre-service teachers tended to update their knowledge about particular issues by searching the relevant online sources. For instance, the pre-service teachers mostly 
watched the teaching videos from YouTube in order to know the way to apply particular teaching techniques. The pre-service teachers also read relevant online sources in order to develop their teaching materials

\section{References}

Ahmed, M. K. (2014). Issues in ESP (English for Specific Purposes). International Journal for Teachers of English, 4(1), 35-59.

Al-Zahrani, M. Y. (2014). The Involvement of the General English Teachers into ESP Practice: Possibilities and Problems in ELI. International Journal of Science Commerce and Humanities, 2(4), 55-73.

Alfaki, I. M. (2014). Professional Development in English Language Teaching: A Teachers' View. European Centre for Research Training and Development, 2(7), 32-49.

Aliakbari, M., \& Nejad, A.M. (2013). On the Effectiveness of Team Teaching in Promoting Learners' Grammatical Proficiency. 36(3),5-22.

Bada, E., \& Okan, Z. (2000). Students' Language Learning Preferences. TESL-EJ, 4(3), $1-18$.

Ballard, C.G., \& Hyalt, L. (2012). Reflection in-action Teaching Strategies Used by Faculty to Enhance Teaching and Learning. Journal for Teacher Researcher. 14(2), 1-11.

Basturkmen, H. (2010). Developing Courses in English for Specific Purposes: Palgrave Macmillan UK.

Belcher, D. D. (2004). Trends in Teaching English For Specific Purposes. Annual Review of Applied Linguistics, 24, 165-186.

Borg, M. (2001). Key Concepts in ELT; Teachers Belief. ELT journal, 55(2), 186-188.

Borg, S. (2003). Teacher cognition in language teaching: A review of research on what language teachers think, know, believe, and do. Language Teaching, 36(2), 81109.

Brown, H. D. (2007). Teaching by Principles: An Interactive Approach to Language Pedagogy $3^{\text {rd }}$ edition. Pearson, USA.

Cao, J. (2014). A Survey on ESP Teaching in Changchun University of Science and Technology. Theory and Practice in Language Studies, 4(12), 2507-2512.

Craft, A. (2000). Continuing Professional Development: A Practical Guide for Teachers and Schools.

Creasy, K.L. (2015). Defining Professionalism in Teacher Education Programs. Journal of Education \& Social Policy. 2 (2), 23-25.

Creswell, J. W. (2012). Educational Research: Planning, Conducting, and Evaluating Quantitative and Qualitative Research: Pearson College Division

Day, C. (1999). Developing Teachers: The Challenges of Lifelong Learning.

Fraenkel, J. R., \& Wallen, N. E. (2009). How to Design and Evaluate Research in Education.

Gatehouse, K. (2001). Key Issues in English for Specific Purposes (ESP) Curriculum Development. The Internet TESL Journal, 7(10). 
Ghanbari, B., \& Rasekh, A. E. (2012). ESP Practitioner Professionalization through Apprenticeship of Practice: The Case of Two Iranian ESP Practitioners. English Language Teaching, 5(2), 112-122.

Goodwyn, A.S.L., Souto, M., Cheruve, R., Tan, M., Reed, R., \& Taveras, L. (2014). What should Teacher Educators Know and be able to do? Perspective from Practicing Teacher Educators. Journal of Teacher EducationI. 65, 284-302.

Graves, K. (2000). Designing language courses: A guide for teachers. Boston: Heinle \& Heinle Publishers.

Guskey, T., R. (2002). Professional Development and Teacher Change. Teachers and Teaching: theory and practice, 8(3/4), 381-390.

Harmer, J. (2007). The Practice of English Language Teaching. Fourth Edition. Harlow, Essex: Pearson Education.

Hatch, J. A. (2012). Doing Qualitative Research in Education Setting. United States of America, State University of New York Press.

Hutchinson, T., \& Waters, A. (1987). English for Specific Purposes: A LearningCentered Approach. In (pp. 5-14). Cambridge: Cambridge University Press.

Johnson, K. (1992). The relationship between teachers' beliefs and practices during literacy instruction for non-native speakers of English. Journal of Literacy Research, 24(83).

Johnson, K. E. (1999). Understanding language teaching: Reasoning in action. Boston: Heihle \& Heinle Publishers.

Kalaja, P., Barcelos, A. M. F., Aro, M., \& Lythy, M. R. (2015). Beliefs, Agency and Identity in Foreign Language Learning and Teaching.

Kazemi, A., \& Ashrafi. (2014). Inservice Training Programs for Iranian EFL Teacher Revisited. International Jurnal of Asian Social Science. 4(10), 1062-1076.

Kumar, R. (2011). Research Methodology: a step-by-step guide for begginers.

Kuzairi. (2014). Professional Development by Senior High School English Teachers in Pamekasan. Unpublished Thesis, State University of Malang, Malang.

Latief, M. A. (2015). Research Methods on Language Learning: An Introduction. Malang: Universitas Negeri Malang.

Liando, N. (2010). Students' VS Teachers' Perspectives on Best Teacher Characteristics in EFL Classroom. TEFLIN Journal, 21(2), 118-136.

Miles, M. B., \& Huberman, A. M. (1994). Qualitative Data Analysis.

Pajares, M. F. (1992). Teachers' Beliefs and Educational Research: Cleaning Up a Messy Construct. Review of Educational Research, 62(3), 307-332.

Park, G. P., \& Lee, H. W. (2006). The Characteristics of Effective English Teachers as Perceived by High School Teachers and Students in Korea. Asia Pacific Education Review, 7(2), 236-248.

Peraturan Menteri Pendidikan dan Kebudayaan No. 87 Tahun 2013 tentang Program Pendidikan Profesi Guru Prajabatan (PPG) retrieved November 26 ${ }^{\text {th }}, 2016$ from http://kelembagaan.ristekdikti.go.id.

Peraturan Menteri Pendidikan Nasional No. 16 Tahun 2007 tentang Standar Kualifikasi Akademik dan Kompetensi Guru retrieved February 11 ${ }^{\text {th }}, 2017$ from http://vervalsp.data.kemdikbud.go.id.

Priajana, N. (2015). Professional Development of Exemplary EFL Teachers. Unpublished Dissertation, State University of Malang, Malang. 
Richards, J. C., \& Farrell, T. S. C. (2005). Professional Development for Language Teachers: Strategies for Teacher Learning: Cambridge University Press.

Thompson, S., Greer, J.G., \& Greer, B.B. (2004). High Qualified for Successful Teaching: Characteristics Every Teacher Should Possess. University of Memphis. Undang-undang No. 14 Tahun 2005 tentang Guru dan Dosen retrieved June 18 ${ }^{\text {th }}, 2017$ from http://sumberdaya.ristekdikti.go.id. 